\title{
Current State and Future Trends to Optimize the Care of Chronic Kidney Disease in African Americans
}

\author{
Kimberly Harding a Tesfaye B. Mersha ${ }^{b}$ Joseph A. Vassalottic, d Fern J. Webb ${ }^{\text {e }}$ \\ Susanne B. Nicholas ${ }^{f}$ \\ ${ }^{a}$ Monarch Innovation Partners, Inc., Rockville, MD, b Department of Pediatrics, Cincinnati Children's Hospital \\ Medical Center, University of Cincinnati, Cincinnati, $\mathrm{OH},{ }^{\mathrm{C}}$ National Kidney Foundation, and d'Division of Nephrology, \\ Department of Medicine, Icahn School of Medicine at Mount Sinai, New York, NY, e Department of Community \\ Health and Family Medicine University of Florida College of Medicine, Jacksonville, FL, fDivisions of Nephrology and \\ Endocrinology, Department of Medicine, David Geffen School of Medicine at University of California, Los Angeles, \\ CA, USA
}

\section{Keywords}

Chronic kidney disease · African Americans · Chronic kidney disease interventions programs · Genetic determinants · Social determinants · Care coordination . Sustainable technology $\cdot$ Health disparities $\cdot$ Call to action more widespread outreach programs, strategies to improve medication adherence, safe and effective pharmacological treatments to control or eliminate CKD, as well as the use of health information technology, and patient-engagement programs for improved CKD outcomes may help to positively impact these disparities among AAs @ 2017 S. Karger AG, Basel

\section{Introduction}

The United States Renal Data System Annual Data Report estimated that the prevalence of chronic kidney disease (CKD) in adults, during the period 2011-2014 was $14.8 \%$ [1]. This represented an increase from 12 to $14 \%$ during the period from 1988-1944 to 1999-2004. Importantly, the prevalence of CKD among African Americans (AAs) is 23.5 times higher compared to Caucasian Americans (CAs). In addition, Medicare spending for patients with CKD aged 65 years and above exceeded USD 50 billion in 2014, representing 20\% of all Medicare spending in this age group. On the other hand, spending per year was $14.6 \%$ higher for AA beneficiaries

\section{KARGER}

(C) 2017 S. Karger AG, Basel 
with CKD than for CAs in 2014, representing an increase from the $12.9 \%$ gap that occurred in 2013 [1].

According to the American Society of Nephrology and the Center for Disease Control and Prevention (CDC), there has been a $30 \%$ increase in CKD over the past decade accounting for more than USD 45 billion in 2012 [2]. Indeed, the Federal government has published health and healthcare disparity reports showing that the widest gaps in CKD outcomes have remained within the AA community [3]. Significant racial and ethnic disparities exist at every stage of CKD with AAs being 10 times more likely to develop kidney failure related to hypertension, and 3 times more likely to progress to kidney failure than CAs [4]. This reflects both a health disparity, defined as a higher burden of illness, injury, disability, or mortality experienced by one population relative to another; and a healthcare disparity, defined by differences between population-specific groups in health insurance coverage, access to and use of care, clinical outcomes, and quality of care [5]. Based on both historic and recent published literature, AAs experience both, as it relates to $\mathrm{CKD}$. The increased risk for $\mathrm{CKD}$ and subsequent endstage renal disease in AAs are due to several factors including higher prevalence and severity of hypertension; inadequate healthcare access; greater predilection to intrinsic vascular disease; greater tendency for developing target organ damage at target blood pressure levels; increased use of illicit drugs; and lower use of less renoprotective medications [6]. According to the Robert Wood Johnson Foundation (RWJF) [7], the National Committee for Quality Assurance [8] and others, social, environmental, and behavioral factors can have a significant negative impact on health outcomes and disturb the economic stability of individuals and populations. These factors contribute up to $60 \%$ of deaths in the United States related to healthcare disparities alone yet only $3 \%$ of national health expenditures are spent on prevention [5]. A greater focus on factors contributing to CKD disparities in AAs may provide an opportunity to improve overall outcomes.

In this review, we discuss the genetic and social determinants of CKD in AAs and the impact of late referrals from primary care physicians (PCPs) to Nephrologists on CKD outcomes. We describe some of the current approaches to alleviate CKD disparities among AAs, the role of care coordination between healthcare professionals and patients and the use of health information technology to enhance patient engagement. We also provide a call to action that delineates specific approaches to reduce CKD disparities for AAs.

Optimizing Care of CKD in AAs

\section{Genetic Determinant Factors Related to AA and CKD}

A number of molecular, environmental, and genetic factors contribute to the earlier onset and progression of CKD in AAs. These include increased salt sensitivity and reduced plasma renin in the face of upregulation of the intra-renal renin-angiotensin system (RAS) independent of systemic RAS [10, 11]. In addition, genetic variation in the apolipoprotein 1 gene-gene and gene environment interactions may account for as much as $70 \%$ of the differences in nondiabetic kidney failure in AAs compared to CAs [12]. This suggests that studies specifically targeting these mechanisms in AAs have the potential to uncover novel therapeutic agents to reduce CKD risk in this population [13]. Other factors that contribute to the disparities in AAs include biologic/genetic, consequences of social, economic, cultural environments and health systems biases [14]. Although several studies have examined these relationships, precise quantification of the relative impact of disparity contributors requires further investigation.

The mechanisms by which environmental factors interact with genetic determinants to affect CKD susceptibility are still unknown. Previous studies have focused on the differences in CKD by self-reported race, making it difficult to delineate the importance of environmental compared with biologic factors [15-17]. Current tools used to estimate the genetic ancestral contributions may provide insight into the genetic etiology of racial disparities in CKD in admixed populations, including AAs [1820]. For example, individuals of African and European populations intermixed during colonization of the New World and passed on indigenous genetic information to newly created AA admixed populations [21]. Thus, a mixed AA background resulted from admixture of African and European ancestral populations and carry unique patterns of genomic information from each accordingly. Also, strategies such as genetic variants informative of ancestry, known as Ancestry Informative Markers are used to calculate estimates that reflect the proportion of ancestry in individuals across the genome [22]. These approaches and correlations of genetic ancestry background with clinical or environmental factors may provide further insight into the racial genetic disparity that exists in CKD. For instance, the finding of an association between percentage African ancestry within admixed AAs could potentially support a genetic or environmental basis for the differential expression of CKD among racial groups. If there is greater global ancestry across the genome in CKD patients relative to controls,

Am J Nephrol 2017;46:176-186 DOI: $10.1159 / 000479481$ 
but no significant rise in local ancestry at a particular locus, this may point to a stronger role for social and environmental factors independent of genetic ancestry. This approach has been used in the field of obesity and diabetes to more accurately explain racial/ethnic differences in health-related outcomes $[23,24]$ and can potentially be applied to CKD in AAs.

\section{Social Determinants Impact CKD Disparities}

Social conditions, including social class, race, income, and education level have been called "fundamental causes of disease" because they entail unequal access to healthpromoting and disease-preventing resources, thereby increasing disease risk in manifold ways [25]. Some of these relationships in general and in relation to CKD have been previously reviewed $[14,26]$. In particular, Braveman and Gottlier [14] reviewed the causes and mechanisms by which social and socioeconomic factors may impact health. Phelan emphasized that race itself is closely linked to resources and that it should also be considered a fundamental cause of health inequality [25]. In the United States, the level of education (less than high school, high school, some college and college graduate) has a gradient effect on life expectancy [14]. McGinnis et al. [27] estimated that only $10-15 \%$ of preventable death in the United States was attributed to overall medical care.

Other findings suggest an etiologic role for social conditions in kidney disease [28]. Socioeconomic status (SES) and social factors may influence risk factors for CKD and CKD progression through the effects of lack of health insurance, residential segregation, prejudice and discrimination on access to healthcare, access to quality care, reduced education/literacy, reduced employment and increased exposure to environmental toxins [26]. Furthermore, studies have investigated the effect of SES on specific CKD-related factors in the following manner. Reduced annual household income <USD 20,000 vs. $>$ USD 75,000 is associated with 1.34 greater odds of microalbuminuria and 2.36 odd of macroalbuminuria [29]. Uninsured versus insured CKD individuals are $40 \%$ less likely to receive appropriate therapy for blood pressure control [30]. Finally, household income $<125$ vs. $>125 \%$ of the Federal Poverty level was associated with 59\% greater odds of CKD, after adjusting for demographics, insurance status, and comorbid conditions [31].

Minority patients with CKD also struggle against bias, prejudice, and discrimination within the healthcare system [32]. Some physicians, according to evidence from patients with different diseases, "perceive minorities more negatively than their majority counterparts" in aspects likely to influence CKD treatment, such as patients' likelihood of risky behavior and adherence to medical advice [33]. Multiple factors outside of the healthcare system also influence health disparities related to CKD. An RWJF report on health disparities denotes that the observed associations between CKD and cumulative exposure to working class status were stronger among AAs who bear a greater burden of kidney disease [7]. The RWJF report also suggested that inter-generational and low SES are associated with CKD, and by no fault of theirs, AAs may be susceptible to CKD based on social origins. The RWJF authors concluded that addressing socioeconomic inequalities, such as social justice and disease prevention, would contribute to decreasing CKD disparities among AAs. Further, the National Library of Medicine showed that low SES, when stratified by race, was significantly associated with CKD in AAs (OR 1.91 ; 95\% CI 1.54-2.38), but not in CAs (OR 0.95; 95\% CI 0.58-1.55), confirming an interaction or effect modification between poverty and AA status on the prevalence of CKD [34]. Similarly, Bruce et al. [35] found affluent AAs in the Jackson Heart Study had a 41\% lower prevalence of CKD than their less affluent counterparts. The World Health Organization acknowledges the inequities in social determinants of health and supports the potential of adaptive policies on general health aimed at improving education and reducing poverty [36].

\section{Impact of Late Referrals on CKD Outcomes in AA}

The definition in the literature of early versus late referral is the time from nephrology consultation to dialysis initiation, with some heterogeneity across studies. Appropriate early intervention by a nephrologist can slow down CKD progression, improve treatment of CKD complications, facilitate creation and maturation of native arteriovenous fistula; and increase access to home dialysis and preemptive kidney transplantation [33]. Clinical Practice Guidelines for referring patients were published in the Kidney Disease Outcomes Quality Initiative by the National Kidney Foundation (NKF) $[37,38]$. The low implementation of these guidelines is reflected in the globally high prevalence of late referrals, which is 30-40\% [39]. The percent of AAs (44.8\%) receiving late referrals is significantly higher than the percent of CAs (24.5\%) [40]. Other patient-related factors that may contribute to late referrals include patient-denial, level of understanding of their disease, cultural differences, low perceived
178
Am J Nephrol 2017;46:176-186 DOI: $10.1159 / 000479481$
Harding/Mersha/Vassalotti/Webb/ Nicholas 
level of urgency, negative perceptions of renal replacement therapy, lack of or inadequate health insurance, poor compliance, inadequate knowledge or education regarding options and language differences [39, 41, 42]. In a 4-year retrospective analysis, Obialo et al. [43] showed that poor SES is a major contributor to late referrals in AAs. Further, "ultralate referral" $(<1$ month between contact with a nephrologist and dialysis initiation) in AA patients was associated with lower hematocrit, lower albumin, lower kidney function, higher use of hemodialysis catheters, and increased morbidity and mortality [43]. Notably, even in the absence of late referral, a 10-year follow up of AAs with hypertensive CKD enrolled in the African American Study of Kidney Disease and Hypertension (AASK) trial showed that AAs with low healthrelated quality of life are at higher risk of adverse outcomes, including cardiovascular events and cardiovascular death [44]. Thus, AAs are a highly susceptible group in which early referrals could potentially minimize already disproportionate risks for CKD-related morbidity and mortality. In addition, clear benefits of early referral lead to increased use of renin-angiotensin-aldosterone system blockers, and optimal management of other comorbidities such as mineral bone disorders [38]. Therefore, early nephrology referral of all CKD patients is highly recommended.

\section{Current Approaches to Alleviate Health Disparities for CKD in AA}

\section{PCP-Specialist Care Coordination of CKD Patients}

Careful, directed collaboration between the PCP and the nephrologist, endocrinologist, cardiologist, and other practitioners has the potential to improve care, clinical outcomes, and mortality rates for all CKD patients. The American Diabetes Association has created a highly effective model for co-management of diabetic kidney disease by the PCP, nephrologist, and the endocrinologist with a goal to achieve current therapeutic clinical guidelines and improve patient outcomes particularly related to glycemic control [45]. In addition, the National Institute of Diabetes and Digestive and Kidney Disease has set annual CKD screening targets as a Healthy People 2020 goal of $37 \%$ of diabetic Medicare beneficiaries [46].

\section{Best Practices for CKD Care Coordination for AA}

Effective coordinated care for CKD patients should include clear definitions of specific roles and responsibilities of each professional to prevent overlap and effort du-

Optimizing Care of CKD in AAs plication. An example of focus areas for CKD stages 3-5 for each practitioner might include clinical focus of the PCP on areas related to health maintenance, hypertension, and lipid management. Diabetes management, diet, and lifestyle modification may be co-managed by the PCP and the endocrinologist, while CKD complications such as mineral and bone disorder may be co-managed with the nephrologist. As CKD progresses from stage 3-5, alterations in diet and lifestyle recommendations typically become the focus of the nephrologist with a renal nutritionist and the PCP playing a supportive role to reinforce these strategies [45].

The Renal Physician Association performed a longitudinal quality improvement study of a tool-based intervention in several nephrology practices and their referring PCP practices [47]. Implementation of specially tailored audits that focused on CKD identification, communication, and patient education were highly effective in augmenting awareness and identification of CKD among PCPs, as well as increasing communication between clinical practices, and better co-management and cooperation between the PCP and the nephrologist [47]. In addition, continuous quality improvement, evaluation, and review cycles, such as the Plan-Do-Study-Act cycles proposed by the Agency for Healthcare Research and Quality should be an intrinsic part of this, or any collaborative effort in the care of chronic diseases [48]. An important component should include multidisciplinary teams consisting of a dietician/nutritionist, social worker, nurse practitioner, physician assistant, and specially trained nursing staff and a clinical pharmacist $[49,50]$ as defined in the Patient-Centered Medical Home model [51].

\section{Impact of Medication Adherence on Health}

Disparities in AA and Patient Safety

Muntner et al. [52] demonstrated that being AA and having low education and low income were associated with worse medication adherence scale scores. In addition, low medication adherence may contribute to risk factors for CKD and CKD disparities in AAs [53]. Specifically, selfreported medication adherence in a prospective cohort of CKD patients demonstrated that lower adherence was associated with adverse safety events including hypoglycemia, medication-related falls, hypotension, and hyperkalemia (prevalence ratio 2.11; 95\% CI 1.08-2.69) [53]. A study by Rifkin et al. [54], which enrolled 30\% AAs, determined that polypharmacy leads to complex medication choices and adherence challenges in $\mathrm{CKD}$. The effect of poor medication adherence on clinical outcomes in AAs with poor

Am J Nephrol 2017;46:176-186

DOI: $10.1159 / 000479481$ 
blood pressure control in a primary care setting was examined by Ogedegbe et al. [55]. The authors demonstrated that increased medication adherence and improved blood pressure control were achieved with patient education supported along with positive-affect induction and self-affirmation ( 42 vs. $36 \%, p=0.049$ ).

The contribution of the clinical pharmacist to improve medication reconciliation and management can be an effective approach to enhance medication adherence to improve patient safety [56] and clinical outcomes. Mason [57] concluded that having a structured pharmacist-conducted medication review and assessment of adherences may assist with identifying and resolving medication-related issues in patients with CKD.

\section{Clinical Trial and Drug Discovery Techniques}

Randomized clinical trials of interventions should be designed to advance standards, and develop new therapies for AAs with CKD. In 1994, the National Institutes of Health (NIH) provided guidelines for the inclusion of minorities and women in clinical trials [58]. However, there remains a dearth of CKD-related clinical trials that enroll, or even target, AAs. Of the more than 3,000 CKDrelated clinical trials registered in clincaltrials.gov (accessed January 3,2016 ), only 34 , or about $1 \%$ were directed toward AAs, whereas AAs comprise $13.2 \%$ of the US population [59]. Arguably, the disparities in CKD justify additional investigation in the AA population than would be expected by the percentage of the population. Until the implementation of the AASK trial, there were only few studies (including studies in cancer and AIDS) that exclusively enrolled AAs by design [60]. Moreover, the few studies that enrolled more than $10 \%$ AAs have made an important impact to transform CKD care of AAs [13]. Notably, the AASK trial (100\% AA) showed that cardio-renal outcomes in AAs are improved with the use of angiontensin converting enzyme inhibitors in comparison to beta-blockers or calcium channel blockers with diuretics and other agents, as necessary [61]. This changed the clinical practice that AAs with hypertension were not offered angiontensin converting enzyme inhibitors, as it was previously thought that this population generally responded poorly to RAS blockers. The AASK trial also demonstrated that AAs with hypertensive kidney disease achieve and sustain appropriate blood pressure control over a long period. Additionally, 3 randomized clinical trials that enrolled a high proportion of AAs with hypertensive nephropathy effectively supported a blood pressure target of $<140 / 90 \mathrm{~mm} \mathrm{Hg}$ to slow CKD progression [62].
Deterrents to AA Participation in Clinical Trials and the Need for Expanded Research

Both patient-related and physician-related barriers for AA participation in large clinical trials should be overcome. Traditional communication methods (i.e., posting flyers in clinics and hospitals) about the existence of clinical trials and recruitment efforts are typically less effective when seeking to engage underrepresented populations [63]. There are differing perceptions regarding recruiting AAs in urban versus rural communities that contribute to their low participation in clinical trials. A study by Bergeron examined rural South Carolina residents and concluded that some of the barriers to participation were accessibility to trial sites, poverty, and lack of awareness of available clinical trials. Better communication of investigators and communication strategies are needed to increase participation of rural AAs [64]. In addition to the typical risk factors that alter $\mathrm{CKD}$ progression, factors that may be more pertinent to AAs include urban stressors, religiosity/church attendance, access to care, cultural values, and health literacy. It is also essential to engage AAs in venues where they frequently congregate and feel most comfortable [65]. These factors should be included in the recruitment strategy of clinical trials to enhance participation of AAs. Recruitment strategies should also include attention to reasons that AAs are lost to follow-up in clinical studies, since 1.9 times (95\% CI 1.1-3.6) higher rates of attrition were observed in participants identified as Afrocentric compared to those not identified as Afrocentric [66]. Several reasons for the higher attrition rates include cultural mistrust, limited minority research investigators, and staff, as well as access to care and difficulties related to transportation [66].

There are no known drug discovery studies specifically targeting CKD progression in AAs, and thus, the potential to explore this area is enormous. For example, in the development of novel pharmacologic therapies, one may consider differences in renal drug transporters in normal kidneys that may be related to ethnic as well as age and gender differences. Joseph et al. [67] examined the gene expression of various drug transporters in normal kidney tissues of age-matched individuals $(n=$ 95) and found that gender-age and gender-ethnicity interactions were important contributors in the expression of several drug transporters. In particular, expression of ATP7B and KCNJB were significantly higher in AA females compared to European American females. Data suggest that similar analysis could potentially im-
180

Am J Nephrol 2017;46:176-186 DOI: $10.1159 / 000479481$
Harding/Mersha/Vassalotti/Webb/ Nicholas 
prove drug usage and dosage toward achieving personalized medicine as well as susceptibility to adverse drug reactions in patients with $\mathrm{CKD}$.

\section{The Role of Health Information Technology and Patient Engagement and CKD Clinical Innovation for AA}

\section{Effective Patient Engagement through Health}

\section{Information Technology}

The use of electronic health (eHealth) records, eHealth, mobile Health (mHealth), and telehealth may improve communication and coordinated care between PCPs and subspecialists for high-risk AAs with CKD. In addition, self-management of patients with CKD by integrating smartphones into usual care is feasible and may be clinically useful [68].

AAs rely heavily on smartphones for health information and make up $67 \%$ compared to $57 \%$ CAs of mHealth users [69]. These statistics support the potential for technology to target and advance AA patient engagement in CKD management through the potential to reduce inequalities and empower ethnic minority groups [70]. The increased use of eHealth is linked to having a college education, a family member with a chronic condition, health insurance, and active social media users in AAs [70]. In fact, significant reductions in systolic and diastolic blood pressures were observed in AAs with uncontrolled hypertension in the Smartphone Medication Adherence Stops Hypertension program compared to standard care $(p<0.0001)$ based on generalized linear mixed modeling [71]. Focus groups show that AAs perceive telemedicine as a useful mechanism for timely access to medical opinions [72]. The incorporation of experts in information technology into a patient navigator program for CKD management [73] can have an enormous impact to improved clinical outcomes in AA CKD patients.

\section{Virtual Provider-to-Provider Collaboration for Care} Coordination

The use of a virtual provider-to-provider platform technology has the potential to revolutionize CKD care for AAs by incorporating a social network and opensource tools that would effectively support clinical decision-making and the coordination of care of this highrisk cohort. In 2007, a roadmap for national action on clinical decision support was proposed by the American Medical Informatics Association 'to ensure optimal, us-

Optimizing Care of CKD in AAs able and effective clinical decision support' is widely available to providers and to patients where and when it is needed to facilitate healthcare decisions [74]. This approach has been implemented in several institutions to systematically improve safe drug prescribing by decreasing adverse drug events in patients with low estimated glomerular filtration rate as a result of reduced ability to excrete the parent drugs and/or potentially harmful metabolites $[75,76]$. The CKD health community must advocate for sustainable health-information technology solutions that enable remote, virtual, and in-person patient engagement models and clinical innovation environments across CKD care teams, Clinical Research Organizations, payers, health networks and their patients, for progressive research discovery worldwide.

Overcoming Gaps in Sustainable Technology Solutions for Clinical Innovation in CKD for $A A$

Efforts to develop sustainable health information technology to reduce CKD among all populations are gaining traction across providers, patient navigators, patient advocacy groups, and payers [77]. However, technology solutions that support the clinical intelligence needed for research related to AAs with CKD appears fragmented. This is due in part to the lack of cohesive technology standards that effectively integrate eHealth records, public health registries for socioeconomic data values, laboratory systems, and medical device information into an integrated data set for most Clinical Research Organizations. As a result, some CKD researchers may not transition effectively from manual data entry methods that would facilitate more robust national and multinational CKD clinical trials and public health innovation efforts [78]. This deficit can directly impede their ability to contribute to the improvement of CKD outcomes in AAs. Figure 1 shows many of the members of the multidisciplinary team involved in the care of AA with CKD.

\section{Evidence-Based Approaches for Addressing Health Disparities in the AA Community}

The development of integrated clinical and social determinant assessment tools related to CKD is gaining greater acceptance. Some of the pivotal programs, such as the NKF Kidney Early Evaluation Program, which successfully conducted an outreach program to over 185,000 individuals, including $33.4 \%$ AAs, at increased risk for

Am J Nephrol 2017;46:176-186 DOI: $10.1159 / 000479481$ 


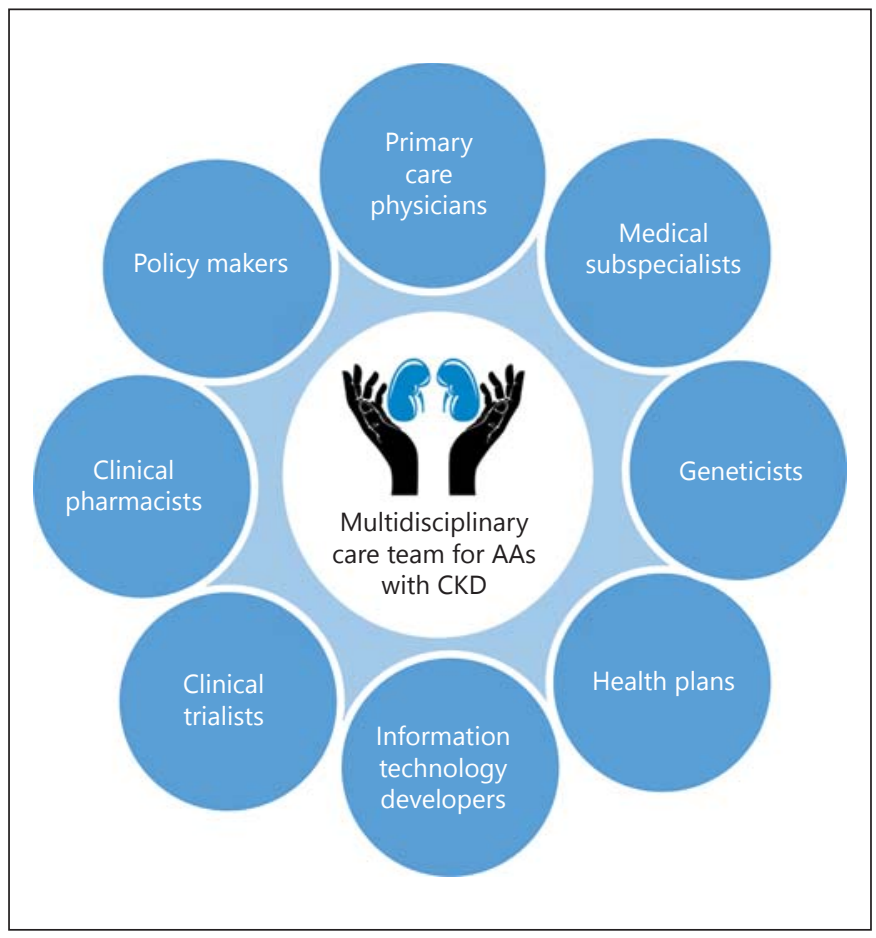

Fig. 1. Conceptual model of a multidisciplinary team involved in care of African Americans (AAs) with chronic kidney disease (CKD). The figure shows members of the multidisciplinary team involved in the care of AAs with CKD.

kidney disease [79] have laid the groundwork for the current generation of national CKD screening and medical intervention programs for high-risk groups. The design used a community-based approach to reach AAs in community centers and churches engaging individuals who may mistrust the health system or have poor access to care. Recent data from Kidney Early Evaluation Program showed that uninsured adults at high risk for developing kidney disease were more likely to progress to kidney failure or death than those with private health insurance coverage [80]. Another example is the NKF CKD intercept program [81], which seeks to facilitate positive changes in large-sized healthcare organizations. The CKD Health Evaluation and Risk Information Sharing (CHERISH) sponsored by the CDC and NKF [82] is a large-scale $\mathrm{CKD}$-screening program that targeted individuals at high risk for CKD, including AAs. The direct impacts of these programs on clinical outcomes in AAs are still being assessed.

Current efforts, both in the federal and private sectors are beginning to address the significant demand for these publically available outreach programs that aim to increase awareness and improve outcomes. For example, the CDC and Research Triangle Institute collaborated to develop a simulation model to assess costs and benefits of various CKD care and prevention interventions [82]. The NIH/National Institute of Diabetes and Digestive and Kidney Disease leads information sharing and funding efforts for CKD prevention and awareness [83]. In addition, one of the Food and Drug Administration missions is to advance the development of safe and effective pharmacological treatments for the control and elimination of CKD [84]. Table 1 lists some of the current national programs and longitudinal clinical studies that target high-risk patient populations. Systematic low resource interventions to target AA outreach in urban centers and safety-net institutions include clinical decision support and mHealth. In addition, clinical trial design should incorporate this vulnerable population for enrollment.

\section{Call to Action Adapted from the CDC Healthypeople. gov Cancer Outreach Program}

The following patient-engagement practices are recommended by the CDC Healthypeople.gov initiative for healthcare organizations to improve healthcare disparities related to prevention and screening outcomes for chronic diseases such as cancer [85], which, if adapted effectively, may have a notable impact to reduce health disparities for AAs with CKD:

- Improve early detection of CKD through more widespread routine screenings

- Implement evidence-based community interventions to increase screening and modify risk behaviors

- Develop research projects that encourage minority groups to participate in clinical trials for CKD and end-stage renal disease prevention

- Conduct formative research about interventions to reduce CKD disparities and improve health. There is a growing need for interventions that are available to people regardless of SES or lifestyle behaviors that also addresses the social environment

- Use a variety of media to market CKD information to diverse populations in a variety of settings

- Expand access to quality CKD care and clinical trials to ensure that minority groups receive equal care and access to the state-of-the-art technology that other patients receive

- Target barriers to CKD screening and other preventive services, such as fear of CKD, perceived cost, and lack of physician referral.
182

Am J Nephrol 2017;46:176-186 DOI: $10.1159 / 000479481$
Harding/Mersha/Vassalotti/Webb/ Nicholas 
Table 1. National CKD assessment and medical intervention programs

\begin{tabular}{llll}
\hline CKD patient & Sponsors & Targeted group & Overview of programs \\
$\begin{array}{l}\text { assessment and } \\
\text { of program }\end{array}$ & & & Source \\
programs & & &
\end{tabular}

\begin{tabular}{lll}
\hline The CKD Health & CDC and & High risk \\
Evaluation and & the National & patients for \\
Risk & Kidney & CKD and \\
Information & Foundation & $\begin{array}{l}\text { those diagnosed } \\
\text { with CKD and } \\
\text { their caregivers }\end{array}$
\end{tabular}

The CHERISH was designed to

identify individuals at high risk for $\mathrm{CKD}$, determine participant's access to follow-up care, and examine the CKD disease course. CDC is using national datasets like National Health and Nutrition Examination Survey (NHANES) and the United States Renal Data System to investigate the epidemiology of CKD in general and special populations. In addition, the CDC collaborates with the Veterans Administration to examine the natural history and health outcomes of CKD

\begin{tabular}{llll}
\hline $\begin{array}{l}\text { CKD health } \\
\text { economic study }\end{array}$ & CDC and & $\begin{array}{l}\text { Public health } \\
\text { analysts, } \\
\text { epidemiologists, } \\
\text { providers, } \\
\text { patient advocates, clini- } \\
\text { cal quality standards } \\
\text { organizations }\end{array}$ & $\begin{array}{l}\text { CDC and RTI international } \\
\text { are conducting cost-effectiveness } \\
\text { studies using a longitudinal (lifetime) } \\
\text { simulation model to assess the costs } \\
\text { prevention interventions. The model } \\
\text { predicts the development, progression, } \\
\text { and complications of CKD, and test the } \\
\text { effectiveness of various public health } \\
\text { interventions. CDC has concluded } \\
\text { that CKD screening should target } \\
\text { people aged 50 or older with diabetes } \\
\text { or high blood pressure, and it is not } \\
\text { cost effective to screen people } \\
\text { ckdsummary.pdf }\end{array}$ \\
& who are not at high risk for CKD
\end{tabular}

\begin{tabular}{|c|c|c|c|c|}
\hline $\begin{array}{l}\text { National Kidney } \\
\text { Disease Education } \\
\text { Program (NKDEP) }\end{array}$ & NIH NIDDK & $\begin{array}{l}\text { Patients, } \\
\text { providers, } \\
\text { pharmacists, } \\
\text { researchers, } \\
\text { general public, } \\
\text { medical } \\
\text { societies/ } \\
\text { associations }\end{array}$ & $\begin{array}{l}\text { NKDEP is one of the leading } \\
\text { knowledge sharing hubs for CKD } \\
\text { prevention and awareness programs. } \\
\text { The overall program focus is to engage } \\
\text { the CKD care team, researchers, and the } \\
\text { patient advocacy community in } \\
\text { improving healthcare outcomes } \\
\text { for those at risk for CKD, with a } \\
\text { strategic focus on minority groups }\end{array}$ & $\begin{array}{l}\text { http://www.niddk.nih. } \\
\text { gov/HEALTH- } \\
\text { INFORMATION/ } \\
\text { HEALTH- } \\
\text { COMMUNICATION- } \\
\text { PROGRAMS/NKDEP/ } \\
\text { Pages/default.aspx }\end{array}$ \\
\hline $\begin{array}{l}\text { The kidney } \\
\text { health initiative }\end{array}$ & $\begin{array}{l}\text { FDA (Food and } \\
\text { Drug } \\
\text { Administration), } \\
\text { NIH, and private } \\
\text { and public } \\
\text { healthcare, } \\
\text { pharmaceutical, } \\
\text { medical device } \\
\text { nonprofit and } \\
\text { for-profit } \\
\text { organizations } \\
\text { and medical } \\
\text { societies }\end{array}$ & $\begin{array}{l}\text { Government } \\
\text { agencies, public } \\
\text { health analysts, } \\
\text { epidemiologists, } \\
\text { providers, } \\
\text { patient advocates, } \\
\text { clinical quality } \\
\text { standards } \\
\text { organizations, } \\
\text { medical } \\
\text { societies/ } \\
\text { associations }\end{array}$ & $\begin{array}{l}\text { Their mission statement: To advance } \\
\text { scientific understanding of the kidney } \\
\text { health and patient safety implications of } \\
\text { new and existing medical products and to } \\
\text { foster development of therapies for } \\
\text { diseases that affect the kidney by creating } \\
\text { a collaborative environment to optimize } \\
\text { evaluation of drugs, devices, biologics, } \\
\text { and food products }\end{array}$ & $\begin{array}{l}\text { http://www.asn-online. } \\
\text { org/khi/ }\end{array}$ \\
\hline
\end{tabular}

http://www.cdc.gov/ diabetes/projects/pdfs/ ckd_summary.pdf 
Table 1. (continued)

\begin{tabular}{|c|c|c|c|c|}
\hline $\begin{array}{l}\text { CKD patient } \\
\text { assessment and } \\
\text { medical intervention } \\
\text { programs }\end{array}$ & $\begin{array}{l}\text { Sponsors } \\
\text { of program }\end{array}$ & Targeted group & Overview of programs & Source \\
\hline CKDintercept & $\begin{array}{l}\text { National Kidney } \\
\text { Foundation }\end{array}$ & $\begin{array}{l}\text { Clinicians, } \\
\text { patients, general public, } \\
\text { government } \\
\text { agencies, health systems, } \\
\text { health insurance } \\
\text { companies, } \\
\text { medical societies and } \\
\text { associations, employers } \\
\text { and other stakeholder } \\
\text { groups }\end{array}$ & $\begin{array}{l}\text { CKDintercept leverages proven strategies in large- } \\
\text { scale change in healthcare to achieve four broad } \\
\text { goals: establish protection and preservation of } \\
\text { kidney health as a national public health priority; } \\
\text { integrate annual CKD testing for at-risk } \\
\text { populations in primary care; integrate detection } \\
\text { and management of CKD into routine primary } \\
\text { care practice; and ensure that everyone living with } \\
\text { clinically significant CKD receives a diagnosis of } \\
\text { CKD and is provided with the resources and tools } \\
\text { necessary to make informed decisions regarding } \\
\text { their kidney health }\end{array}$ & $\begin{array}{l}\text { https://www.kidney. } \\
\text { org/CKDintercept }\end{array}$ \\
\hline
\end{tabular}

\section{Conclusion}

This review has described some of the persistent problems that contribute to CKD health disparities among AAs with CKD. AAs are already at higher risk for poor access to care and reduced quality of care that ultimately result in worse health outcomes than any other racial group in the United States. Other contributing factors include the biological/genetic predisposition to CKD, and socioeconomic health determinants that are exacerbated by a lack of effective prioritization in the federal, public, and private healthcare sectors. Adoption of the transformational initiatives at the national level in Table 1 could reverse the trend in poor outcomes for this population. In addition, the CDC Healthypeople.gov 2020 initiative designed to bridge both health and healthcare disparities at the national level, should be embraced by the CKD healthcare community in order to meaningfully change experiences of AAs with CKD. The long-term effect will improve the quality of care for AAs at risk for, or with CKD and ultimately, contribute to the development of a reusable framework for other high-risk groups with similar health disparities in the United States and internationally.

\section{Acknowledgment}

The authors thank Liane Hannah, Research Associate at the University of Florida Department of Community Health and Family Medicine for assisting with literature searches, and Elizabeth Montgomery, Senior Project Director of the Primary Care Initiative at the NKF for her contribution to the preparation of this manuscript; and also Rebecca Roberts for her contribution. This work was supported by NIH grant R01HL132344 to TBM; and NIH grants 1DP3 DK094311 and UL1TR000124 to SBN.

\section{Disclosure Statement}

The authors claim no conflict of interest. The content is solely the responsibility of the authors and the authors declare that they have no relevant financial interests.

\section{References}

-1 Saran R, Li Y, Robinson B, Abbott KC, Agodoa LY, Ayanian J, Bragg-Gresham J, Balkrishnan R, Chen JL, Cope E, Eggers PW, Gillen D, Gipson D, Hailpern SM, Hall YN, He K, Herman W, Heung M, Hirth RA, Hutton D, Jacobsen SJ, Kalantar-Zadeh K, Kovesdy CP, Lu Y, Molnar MZ, Morgenstern $\mathrm{H}$, Nallamothu B, Nguyen DV, O'Hare AM, Plattner B, Pisoni R, Port FK, Rao P, Rhee CM, Sakhuja A, Schaubel DE, Selewski DT,
Shahinian V, Sim JJ, Song P, Streja E, Kurella Tamura M, Tentori F, White S, Woodside K, Hirth RA: US Renal Data System 2015 Annual Data Report: epidemiology of Kidney Disease in the United States. Am J kidney Dis 2016;67:S1-S305.

2 Saran R, Li Y, Robinson B, Ayanian J, Balkrishnan R, Bragg-Gresham J, Chen JT, Cope E, Gipson D, He K, Herman W, Heung M, Hirth RA, Jacobsen SS, Kalantar-Zadeh K,
Kovesdy CP, Leichtman AB, Lu Y, Molnar MZ, Morgenstern H, Nallamothu B, O'Hare AM, Pisoni R, Plattner B, Port FK, Rao P, Rhee CM, Schaubel DE, Selewski DT, Shahinian V, Sim JJ, Song P, Streja E, Kurella Tamura $\mathrm{M}$, Tentori F, Eggers PW, Agodoa LY, Abbott KC: US Renal Data System 2014 Annual Data Report: epidemiology of Kidney Disease in the United States. Am J kidney Dis 2015; 66:S1-S305. 
3 http://www.niddk.nih.gov/healthinformation/health-statistics/Pages/kidneydisease-statistics-unitedstates.aspx (accessed April 15, 2017).

4 http://www.asn-online.org/policy/webdocs/ HealthDisparities.pdf (accessed April 15, 2017).

5 http://files.kff.org/attachment/Issue-BriefDisparities-in-Healthand-Health-Care-FiveKey-Questions-and-Answers (accessed April 2017).

6 Agodoa L: Lessons from chronic renal diseases in African Americans: treatment implications. Ethn Dis 2003;13(2 suppl 2):S118S124.

7 Braveman PA, Egerter SA, Woolf SH, Marks JS: When do we know enough to recommend action on the social determinants of health? Am J Prev Med 2011;40(1 suppl 1): S58-S66.

8 https://ncqa.org/hedis-quality-measurement/ research/scan-of-clas-anddisparitiesreduction-activities (accessed April 15, 2017).

9 National Quality Forum: Risk Adjustment for Socioeconomic Status or other Sociodemographic Factors Technical Report. National Quality Forum, August 2014, pp 1-97.

10 Grim CE, Robinson M: Blood pressure variation in blacks: genetic factors. Semin Nephrol 1996;16:83-93.

11 Williams SF, Nicholas SB, Vaziri ND, Norris KC: African Americans, hypertension and the renin angiotensin system. World J Cardiol 2014;6:878-889.

12 Palmer ND, Freedman BI: APOL1 and progression of nondiabetic nephropathy. J Am Soc Nephrol 2013;24:1344-1346.

13 Williams SF, Vaziri ND, Nicholas SB, Norris KC: ACEIs as antihypertensives in African Americans - A 21st Century Perspective; in OM A (ed): ACE Inhibitors in Medicine, Uses, Mechanisms of Action and Potential Adverse Effects. New York, Nova Science Publishers, Inc., 2014, vol. 2, pp 42-72.

14 Braveman P, Gottlieb L: The social determinants of health: it's time to consider the causes of the causes. Public Health Rep 2014; 129(suppl 2):19-31.

15 Gutierrez OM, Isakova T, Smith K, Epstein $\mathrm{M}$, Patel N, Wolf M: Racial differences in postprandial mineral ion handling in health and in chronic kidney disease. Nephrol Dial Transplant 2010;25:3970-3977.

16 Gutierrez OM, Parsa A, Isakova T, Scialla JJ, Chen J, Flack JM, Nessel LC, Gupta J, Bellovich KA, Steigerwalt S, Sondheimer JH, Wright JT Jr, Feldman HI, Kusek JW, Lash JP, Wolf M: Genetic African ancestry and markers of mineral metabolism in CKD. Clin J Am Soc Nephrol 2016;11:653-662.

17 Peralta CA, Lin F, Shlipak MG, Siscovick D, Lewis C, Jacobs DR Jr, Bibbins-Domingo K: Race differences in prevalence of chronic kidney disease among young adults using creatinine-based glomerular filtration rate-estimating equations. Nephrol Dial Transplant 2010; 25:3934-3939.
Alexander DH, Novembre J, Lange K: Fast model-based estimation of ancestry in unrelated individuals. Genome Res 2009;19:16551664.

19 Pritchard JK, Stephens M, Donnelly P: Inference of population structure using multilocus genotype data. Genetics 2000;155:945-959.

-20 Sankararaman S, Sridhar S, Kimmel G, Halperin E: Estimating local ancestry in admixed populations. Am J Hum Genet 2008;82:290303.

21 Ding L, Wiener H, Abebe T, Altaye M, Go RC, Kercsmar C, Grabowski G, Martin LJ, Khurana Hershey GK, Chakorborty R, Baye TM: Comparison of measures of marker informativeness for ancestry and admixture mapping. BMC Genomics 2011;12:622.

22 Mersha TB: Mapping asthma-associated variants in admixed populations. Front Genet 2015;6:292.

23 Cheng CY, Reich D, Coresh J, Boerwinkle E, Patterson N, Li M, North KE, Tandon A, Bailey-Wilson JE, Wilson JG, Kao WH: Admixture mapping of obesity-related traits in African Americans: the Atherosclerosis Risk in Communities (ARIC) Study. Obesity 2010; 18:563-572.

24 Cheng CY, Reich D, Haiman CA, Tandon A, Patterson N, Selvin E, Akylbekova EL, Brancati FL, Coresh J, Boerwinkle E, Altshuler D, Taylor HA, Henderson BE, Wilson JG, Kao WH: African ancestry and its correlation to type 2 diabetes in African Americans: a genetic admixture analysis in three U.S. population cohorts. PLoS One 2012;7:e32840.

25 Phelan JC, Link BG, Tehranifar P: Social conditions as fundamental causes of health inequalities: theory, evidence, and policy implications. J Health Soc Behav 2010;51(suppl): S28-S40.

26 Nicholas SB, Kalantar-Zadeh K, Norris KC: Socioeconomic disparities in chronic kidney disease. Adv Chronic Kidney Dis 2015;22:615.

27 McGinnis JM, Williams-Russo P, Knickman JR: The case for more active policy attention to health promotion. Health Aff (Millwood) 2002;21:78-93.

28 http://www.asnonline.org/Health+Disparitie s+Symposium+Renal+Week (accessed February 2017).

29 Crews DC, McClellan WM, Shoham DA, Gao L, Warnock DG, Judd S, Muntner P, Miller ER, Powe NR: Low income and albuminuria among REGARDS (Reasons for Geographic and Racial Differences in Stroke) study participants. Am J Kidney Dis 2012;60: 779-786

- 30 Hall YN, Rodriguez RA, Boyko EJ, Chertow GM, O'Hare AM: Characteristics of uninsured Americans with chronic kidney disease. J Gen Intern Med 2009;24:917-922.

31 Crews DC, Charles RF, Evans MK, Zonderman AB, Powe NR: Poverty, race, and CKD in a racially and socioeconomically diverse urban population. Am J Kidney Dis 2010;55: 992-1000.
32 Good MJD, Good BJ, Becker AE: The culture of medicine and racial, ethnic and class disparities in health care; in Smedley BD, Stith AY, Nelson AR (eds). National Library of Medicine, National Institutes of Health, National Academy of Science, 2003, p 27.

33 Baer G, Lameire N, Van Biesen W: Late referral of patients with end-stage renal disease: an in-depth review and suggestions for further actions. NDT Plus 2010;3:17-27.

34 Young BA: The interaction of race, poverty, and CKD. Am J Kidney Dis 2010;55:977980.

35 Bruce MA, Beech BM, Crook ED, Sims M, Wyatt SB, Flessner MF, Taylor HA, Williams DR, Akylbekova EL, Ikizler TA: Association of socioeconomic status and CKD among African Americans: the Jackson Heart Study. Am J Kidney Dis 2010;55:10011008.

36 Carey G, Crammond B, Malbon E, Carey N: Adaptive policies for reducing inequalities in the social determinants of health. Int J Health Policy Manag 2015;4:763-767.

37 Inker LA, Astor BC, Fox CH, Isakova T, Lash JP, Peralta CA, Kurella Tamura M, Feldman HI: KDOQI US commentary on the 2012 KDIGO clinical practice guideline for the evaluation and management of CKD. Am J Kidney Dis 2014;63:713-735.

- 38 Vassalotti JA, Centor R, Turner BJ, Greer RC, Choi M, Sequist TD; National Kidney Foundation Kidney Disease Outcomes Quality Initiative: Practical approach to detection and management of chronic kidney disease for the primary care clinician. Am J Med 2016;129: 153-162.e7.

39 Herget-Rosenthal S, Quellmann T, Linden C, Hollenbeck M, Jankowski V, Kribben A: How does late nephrological co-management impact chronic kidney disease? - an observational study. Int J Clin Pract 2010;64:17841792.

40 Kinchen KS, Sadler J, Fink N, Brookmeyer R, Klag MJ, Levey AS, Powe NR: The timing of specialist evaluation in chronic kidney disease and mortality. Ann Intern Med 2002;137: 479-486.

41 Greer RC, Ameling JM, Cavanaugh KL, Jaar BG, Grubbs V, Andrews CE, Ephraim P, Powe NR, Lewis J, Umeukeje E, Gimenez L, James S, Boulware LE: Specialist and primary care physicians' views on barriers to adequate preparation of patients for renal replacement therapy: a qualitative study. BMC Nephrol 2015;16:37.

42 Navaneethan SD, Aloudat S, Singh S: A systematic review of patient and health system characteristics associated with late referral in chronic kidney disease. BMC Nephrol 2008;9: 3.

43 Obialo CI, Ofili EO, Quarshie A, Martin PC: Ultralate referral and presentation for renal replacement therapy: socioeconomic implications. Am J Kidney Dis 2005;46:881886. 
44 Porter A, Fischer MJ, Wang X, Brooks D, Bruce M, Charleston J, Cleveland WH, Dowie D, Faulkner M, Gassman J, Hiremath L, Kendrick C, Kusek JW, Norris KC, ThornleyBrown D, Greene T, Lash JP; AASK Study Group: Quality of life and outcomes in African Americans with CKD. J Am Soc Nephrol 2014;25:1849-1855.

-45 Bowman BT, Kleiner A, Bolton WK: Comanagement of diabetic kidney disease by the primary care provider and nephrologist. Med Clin North Am 2013;97:157-173.

46 https://www.healthypeople.gov/2020/AboutHealthy-People (accessed April 2017).

47 Haley WE, Beckrich AL, Sayre J, McNeil R, Fumo P, Rao VM, Lerma EV: Improving care coordination between nephrology and primary care: a quality improvement initiative using the renal physicians association toolkit. Am J Kidney Dis 2015;65:67-79.

48 Clancy CM: Kidney-related diseases and quality improvement: AHRQ's role. Clin J Am Soc Nephrol 2011;6:2531-2533.

-49 Bolton WK: Nephrology nurse practitioners in a collaborative care model. Am J Kidney Dis 1998;31:786-793.

50 Holley JL, McGuirl K: Advanced practice nurses in ESRD: varied roles and a cost analysis. Nephrol News Issues 2000;14:18-20, 23, 27 passim.

51 Scuderi C, Lee K, Shah N, Bilello L, Webb F: Team-based care: the who of the patient-centered medical home. Osteopath Fam Physician 2014;6:22-27.

- 52 Muntner P, Judd SE, Krousel-Wood M, McClellan WM, Safford MM: Low medication adherence and hypertension control among adults with CKD: data from the REGARDS (Reasons for Geographic and Racial Differences in Stroke) Study. Am J Kidney Dis 2010;56:447-457.

53 Hsu KL, Fink JC, Ginsberg JS, Yoffe M, Zhan M, Fink W, Woods CM, Diamantidis CJ: Selfreported medication adherence and adverse patient safety events in CKD. Am J Kidney Dis 2015;66:621-629.

54 Rifkin DE, Laws MB, Rao M, Balakrishnan VS, Sarnak MJ, Wilson IB: Medication adherence behavior and priorities among older adults with CKD: a semistructured interview study. Am J Kidney Dis 2010;56:439-446.

55 Ogedegbe GO, Boutin-Foster C, Wells MT, Allegrante JP, Isen AM, Jobe JB, Charlson ME: A randomized controlled trial of positive-affect intervention and medication adherence in hypertensive African Americans. Arch Intern Med 2012;172:322-326.

56 St Peter WL, Wazny LD, Patel UD: New models of chronic kidney disease care including pharmacists: improving medication reconciliation and medication management. Curr Opin Nephrol Hypertens 2013;22:656-662.

57 Mason NA: Polypharmacy and medicationrelated complications in the chronic kidney disease patient. Curr Opin Nephrol Hypertens 2011;20:492-497.

$58 \mathrm{http} / /$ grants.nih.gov/grants/guide/noticefiles/NOT-OD-00-048.html (accessed April $15,2017)$

59 http://www.census.gov (accessed May 17, 2016).

60 Phillips RA, Faulkner M, Gassman J, Jaen L, Kusek JW, Norris K, Ojo A: Recruitment of African Americans with chronic renal insufficiency into a multicenter clinical trial: the African American study of kidney disease and hypertension. J Clin Hypertens 2004;6:430-436.

61 Brenner BM, Cooper ME, de Zeeuw D, Keane WF, Mitch WE, Parving HH, Remuzzi G, Snapinn SM, Zhang Z, Shahinfar S, Investigators RS: Effects of losartan on renal and cardiovascular outcomes in patients with type 2 diabetes and nephropathy. $\mathrm{N}$ Engl J Med 2001;345:861-869.

62 Taler SJ, Agarwal R, Bakris GL, Flynn JT, Nilsson PM, Rahman M, Sanders PW, Textor SC, Weir MR, Townsend RR: KDOQI US commentary on the 2012 KDIGO clinical practice guideline for management of blood pressure in CKD. Am J Kidney Dis 2013;62:201-213.

63 Tanner A, Bergeron CD, Zheng Y, Friedman DB, Kim SH, Foster CB: Communicating effectively about clinical trials with African American communities: a comparison of African American and white information sources and needs. Health Promot Pract 2016;17:199-208.

64 Bergeron CD, Foster C, Friedman DB, Tanner A, Kim SH: Clinical trial recruitment in rural South Carolina: a comparison of investigators' perceptions and potential participant eligibility. Rural Remote Health 2013;13:2567.

65 Khubchandani J, Balls-Berry J, Price JH, Webb FJ: Community-Engaged Strategies to Increase Diversity of Participants in Health Education Research. Health Promot Pract 2016;17:323-327.

66 Langford AT, Resnicow K, Davis RE, Alexander GL, Calvi J, Weise C, Tolsma D: Ethnic identity predicts loss-to-follow-up in a health promotion trial. Contemp Clin Trials 2010; 31:414-418.

67 Joseph S, Nicolson TJ, Hammons G, Word B, Green-Knox B, Lyn-Cook B: Expression of drug transporters in human kidney: impact of sex, age, and ethnicity. Biol Sex Differ 2015;6:4.

68 Ong SW, Jassal SV, Miller JA, Porter EC, Cafazzo JA, Seto E, Thorpe KE, Logan AG: Integrating a smartphone-based self-management system into usual care of advanced CKD. Clin J Am Soc Nephrol 2016;11:1054-1062.

69 http://www.pewresearch.org/facttank/2015/04/30/racial-and-ethnicdifferences-in-how-people-use-mobiletechnology/ (accessed April 2017).

70 Chisolm DJ, Sarkar M: E-health use in African American internet users: can new tools address old disparities? Telemed J E Health 2015;21:163-169.
Davidson TM, McGillicuddy J, Mueller M, Brunner-Jackson B, Favella A, Anderson A, Torres M, Ruggiero KJ, Treiber FA: Evaluation of an mHealth Medication Regimen SelfManagement Program for African American and Hispanic Uncontrolled Hypertensives. J Personalized Med 2015;5:389-405.

72 George S, Hamilton A, Baker RS: How do low-income urban African Americans and latinos feel about telemedicine? A diffusion of innovation analysis. Int J Telemed Appl 2012; 2012:715194.

73 Jolly SE, Navaneethan SD, Schold JD, Arrigain S, Konig V, Burrucker YK, Hyland J, Dann P, Tucky BH, Sharp JW, Nally JV: Development of a chronic kidney disease patient navigator program. BMC Nephrol 2015;16:69.

74 Osheroff JA, Teich JM, Middleton B, Steen EB, Wright A, Detmer DE: A roadmap for national action on clinical decision support. J Am Med Informat Assoc 2007;14:141-145.

75 Hug BL, Witkowski DJ, Sox CM, Keohane CA, Seger DL, Yoon C, Matheny ME, Bates DW: Occurrence of adverse, often preventable, events in community hospitals involving nephrotoxic drugs or those excreted by the kidney. Kidney Int 2009;76:1192-1198.

76 Hug BL, Witkowski DJ, Sox CM, Keohane CA, Seger DL, Yoon C, Matheny ME, Bates DW: Adverse drug event rates in six community hospitals and the potential impact of computerized physician order entry for prevention. J General Int Med 2010;25:31-38.

77 Diamantidis CJ, Becker S: Health information technology (IT) to improve the care of patients with chronic kidney disease (CKD). BMC Nephrol 2014;15:7.

78 Harding K: Global health innovation technolgoy models. Nanobiomedicine 2016;3:1-12.

79 Vassalotti JA, Li S, McCullough PA, Bakris GL: Kidney early evaluation program: a community-based screening approach to address disparities in chronic kidney disease. Semin Nephrol 2010;30:66-73.

80 Jurkovitz CT, Li S, Norris KC, Saab G, Bomback AS, Whaley-Connell AT, McCullough PA; KEEP Investigators: Association between lack of health insurance and risk of death and ESRD: results from the kidney early evaluation program (KEEP). Am J Kidney Dis 2013; 61:S24-S32.

81 http://www.kidney.org/CKDintercept (accessed May 18, 2016).

82 http://www.cdc.gov/diabetes/projects/pdfs/ ckd_summary.pdf (accessed April 15, 2017).

83 http://www.niddk.nih.gov/HEALTHINFORMATION/HEALTH-COMMUNI CATION-PROGRAMS/NKDEP/Pages/ default.aspx (accessed April 15, 2017).

$84 \mathrm{http} / / / \mathrm{www}$.asn-online.org/khi/ (accessed April 15, 2017).

85 http://www.cdc.gov/cancer/healthdisparities/basicinfo/disparities.htm (accessed April $15,2017)$ 